\title{
Redefining Urban Landscape Regarding Scientific Realism Philosophy of Science
}

\author{
Ahmadali Namdarian ${ }^{1} \mid$ Somayeh Khani ${ }^{2}$ | Esmaeil Shieh ${ }^{3}$ | Miquel Marti Casanova ${ }^{4}$ \\ Received: 2020-02-04 | in its final version: 2021-02-22
}

Abstract

\begin{abstract}
The concept of urban landscape faces many complexities and ambiguities. These ambiguities lead to misunderstandings between academic sources and professional society. The "scape" and "landscape" terms also have changed from their origin. The term of "image" and concept of legibility makes it more complex There are some disciplines referring to the concept of urban landscape. Each of these disciplines knows itself as the responsible of the urban landscape. This article tries to review the various literature of these two concepts counting the complexities of these terms and then presents new definition for them. This article tries to review various notions about urban landscape and image through content analysis and library studies. Urban landscape of each city is the emergence of reality of that city. It could not be reduced to an objective issue, neither is it subjective being shaped separate from objective one. Urban landscape has been judged by dominant philosophies of science in specific time. This research tries to go behind the various definition of urban landscape which have been presented in different time. After that, it provides a new framework through "scientific realism". From the scientific realism point of view, previous definition reduces the anthology of urban landscape to its epistemology. According to this approach, mechanisms should be considered in presenting a new framework. According to critical realism and regarding Lefebvre's reading of phenomenological materialism and by using Lefebvre's production space theory and influential forces in semiotic dimension of urban landscape, a new theoretical framework could be suggested.
\end{abstract}

Keywords: Philosophy of science; scientific realism; production of space

Citation

Namdarian, A. et al. (2021). Redefining Urban Landscape regarding Scientific Realism Philosophy of Science. ACE: Architecture, City and Environment, 16(46), 9202. DOI: http://dx.doi.org/10.5821/ace.16.46.9202

\section{Redefiniendo el paisaje urbano con respecto a la Filosofía de la Ciencia y el Realismo Científico}

Resumen

\begin{abstract}
El concepto de paisaje urbano se enfrenta a muchas complejidades y ambigüedades. Estas ambigüedades conducen a malentendidos entre las fuentes académicas y la sociedad profesional. Los términos "entorno" y "paisaje" también han cambiado desde su origen. El término de "imagen" y concepto de legibilidad lo hace más complejo. Hay algunas disciplinas que se refieren al concepto de paisaje urbano. Cada una de estas disciplinas se conoce a sí misma como responsable del paisaje urbano. Este artículo intenta revisar la literatura diversa de estos dos conceptos contando las complejidades de estos términos y luego presenta una nueva definición para ellos. Este artículo intenta revisar varias nociones sobre paisaje urbano e imagen a través del análisis de contenido y estudios bibliotecarios. El paisaje urbano de cada ciudad es el surgimiento de la realidad de esa ciudad. No se puede reducir a una cuestión objetiva, ni tampoco se le da forma subjetiva a la objetiva. El paisaje urbano ha sido juzgado por las filosofías de la ciencia dominantes en un tiempo específico. Esta investigación intenta ir más allá de las distintas definiciones de paisaje urbano que se han presentado en diferentes épocas. Además, proporciona un nuevo marco a través del "realismo científico". Desde el punto de vista del realismo científico, la definición anterior reduce la antología del paisaje urbano a su epistemología. Acorde a este enfoque, se deben considerar mecanismos al presentar un nuevo marco. Este nuevo marco teórico podría sugerirse a razón del realismo crítico, la lectura de Lefebvre sobre el materializmo fenomenológico y utilizando su teoría de la producción del espacio y las fuerzas influyentes en la dimensión semiótica del paisaje urbano.
\end{abstract}

Palabras clave: Filosofía de la Ciencia, realismo científico, producción del espacio

PhD in Urban Design, Faculty of Architecture and Environmental Design, IUST (Iran University of Science and Technology), (ORCiD: 0000-0002-7197-0384), ${ }^{2}$ PhD in Islamic architecture, Faculty of Architecture and Urban Planning, Tabriz Islamic Art University, ${ }^{3}$ Professor of Urban Planning, IUST, ${ }^{4}$ PhD, Architect, Assistant professor of UPC (0000-0001-8839-5905), Barcelona, Spain, the supervision of visiting research at UPC. Contact e-mail: ahmadnamdarian@yahoo.com 


\section{Introduction}

Image and townscape are two key and even challenging subjects among urban designers, architectures, and environmental designers. This overlapping even leads to a misunderstanding. These concepts are main concerns of urban design from its birth, and they also change in the line of urban design evolution. The young literature of urban design and verbal similarity with landscape architecture increase this ambiguity. From decision maker's point of view, townscape has even been reduced to some facade guidelines, codes and briefs that could release cities from chaos. This article tries to review various understandings of the image, urban landscape. Then, it is going to give its own definition through presenting a new theoretical framework codification. This framework is going to be investigated through phenomenological-semeiotic approach.

\section{Research Methodology}

This article tries to review various notions about urban landscape and image through library studies. These theories are analysised through qualitative content analysis and the conventional and directed content analysis approach of content analysis. In this type of analysis, the theory is created as parallel as data gathering. Content analysis helps to make a functional model of urban landscape (Saroukhani, 1994; Kondracki \& Wellman, 2002). Usually, this type of analysis is usesed when there is not a good theory explaning data.

The literature of urban landscape has been reviewed and the categories are prepared regarding the role of observer, subject, and the perception mechanism of human. Based on literature review, these three dimensions (object, subject, and perception) are the main elements of urban landscape in different theories. Then, these elements compare with the theoretical framework of philosophy of science. There is a correlation between various paradigms of philosophy of science and the elements of urban landscape. The definition of urban landscape has changed chronologically. These changes in definition have been compared with science philosophy (Figure 1).

Urban landscape theories originated in scientific paradigms, which are also the result of changes in science and philosophy of science. Reviewing different theories shows that city and urban landscape are usually investigated through positivism and critical rationalism focusing on describing urban landscape rather than the mechanism which produces it. Then, urban landscape has been evaluated as separate themes due to the dialectic, which has affected scientific recognition for centuries. However, city and urban landscape are not independent concepts. In this line, this article classifies urban landscape theories through the evolutions of scientific philosophy and Henri Lefebvre's production of space.

A review of the background shows that urban landscape has been investigated according to Hegelian or Marxian dialectic, transected in a synthesis from two contradictory concepts. However, studying Lefebvre's notions shows that urban landscape is a whole, composed of three similar parts; and there is no priority among these three parts. These three parts of urban landscape are perceived scape; conceived scape and lived scape, which could be produced through semiotic approach: Spatial Practice, Spatial Representation and Representational Space. Moreover, this article uses the concept of "urban landscape producing forces" for making this relationship clearer discussion. 
Figure 1. Methodology and conceptual model of research

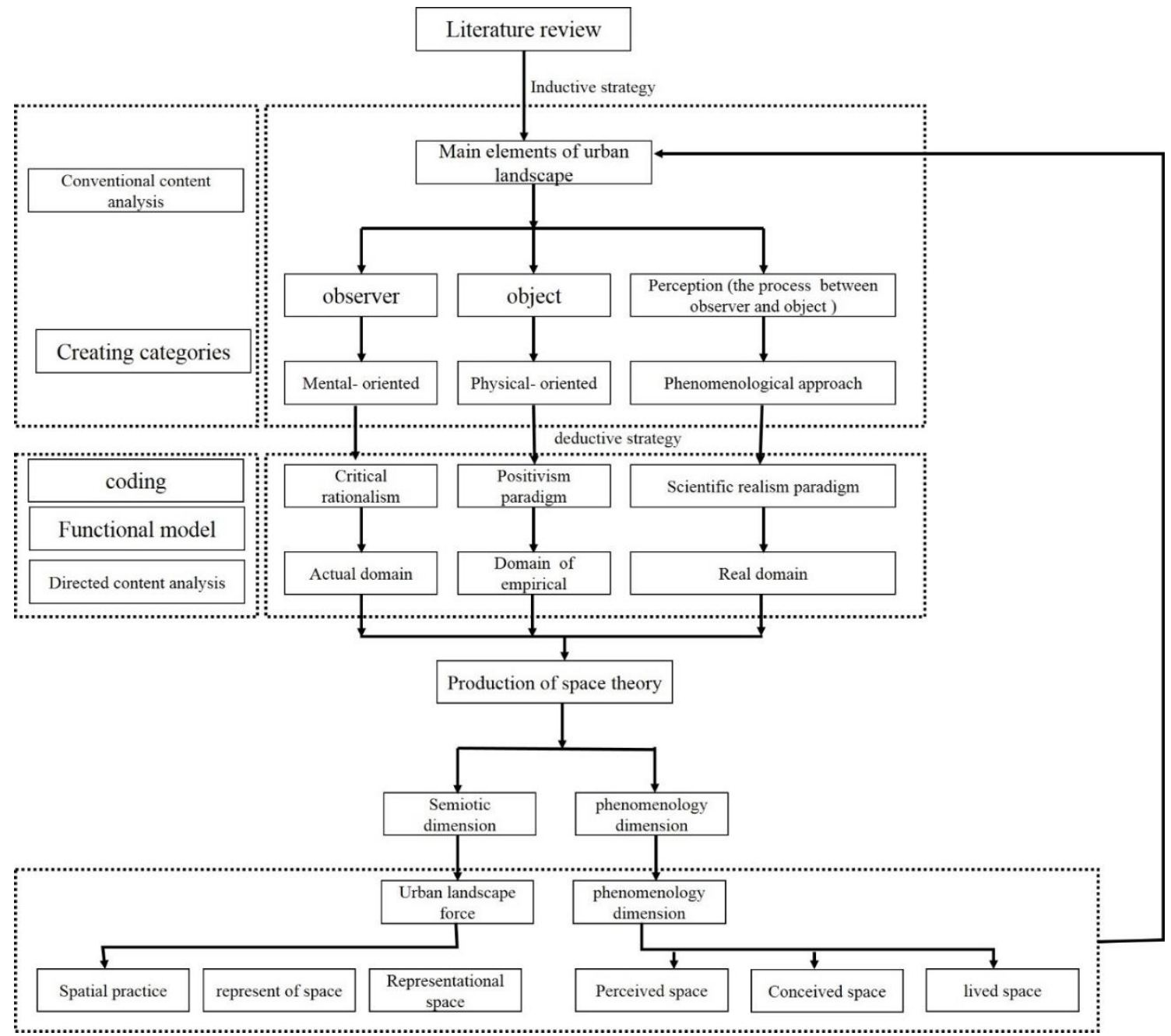

Source: Prepared by the authors.

\section{Literature review}

Urban landscape is one of the main subjects of urban design, architecture and landscape architecture, and different theorists have talked about it (Carmona, Heath, Oc, \& Tiesdell, 2003; Cullen, 1961; Faizi; \& Razzaghi, 2008; Golkar, 2006; Lynch, 1984; Schuyler, 1988; Council of Europe, 2000). Firstly, to enlighten the subject, the origin of scape should be clarified. "The word Scape came from Scappen, which is a German or Dutch word meaning shaping something magisterial." However, in modern English, it takes a distance from its original meaning. Then, landscape, born in the XVII century, meant "shaping land". Before any other thing, it refers to a European painter's style presenting sights manipulated by human (Beheshti, 2016). Aldrich also studies the development of the suffix "scape". He introduces these terms according to valid dictionaries: townscape, airscape, skyscape, waterscape, seascape, snowscape, riverscape, moonscape, cloudscape (Aldrich, 1966). These mentioned terms are visual-based, and in his point of view, they are usually used in visual arts. Cultural Landscape is also the term coined in the beginning of the twentieth century and refers to areas created through the interaction of human and nature. "Landscape means an area, as perceived by people whose character 
is the result of the action and interaction of natural and/ human factors" (Council of Europe, 2000, p. 9). Urban landscape highlights more patently the man-nature relationship that occurs in the territory in a permanent transformation, where its inhabitants' perception plays an important role in its comprehension (Bergamini, 2019).

Nowadays, scape and landscape are changed into suffixes refering to various concepts. For example, Gordon Cullen uses townscape to refer to continuous scape of town. After him, there are many theorists developing this term (Tavernor, 2004; Taylor, 1999; Whistler \& Reed, 1977). Conzen believes that cities have their own roles and their situation and density affect their neighboring areas. Thus, each city produces its own scape about its own function (Conzen, 2004). Giberd indicates four elements for urban landscape: objects, spaces, movement, and time. In his point of view, objects (buildings) with their forms, textures, colors, masses, and lines are the most important elements of urban landscape (Gurer, 2012).

Urban landscape has been evaluated from various point of view. However, some of them interpret urban landscape as a fixed matter rather than the dynamic character of it. It has been juged as a final product rather than a process producing it. Merrifield explains these two terms (product and process) and he compares them with the two main fields of quantum scince: wave and particles (Merrifield, 1993). It seems that urban landscape definition has changed regarding different views of philosophy of science. Roy Bhaskar enumerates three main traditions in philosophy of science: empirical realism, transcendental idealism, and critical realism (Bhaskar, 2013). Blaikie also talks about three main paradigms in history of science: positivism, critical rationalism, and scientific realism (Blaikie, 2000). It could be mentioned that the ontology of urban landscape is mainly influenced by positivism paradigm due to the determination of natural science. This paradigm believes in neutrality of observer in recognizing nature and environment (Hume \& Roberts, 1967).

This viewpoint believes that "Only that which can be observed, that is experienced by the senses, can be regarded as real and therefore worthy of the attention of science (Blaikie, 2000, p. 102). Moreover, its "epistemological assumption is considered to be produced through the use of human senses and by means of experimental or comparative analysis" (ibid). Senses produce observations or data. Then, whatever you see is the same thing that really exists (Aliyu, Bello, Kasim, \& Martin, 2014; Antwi \& Hamza, 2015). "Mechanisms, events and experiences thus constitute three overlapping domains of reality, viz. The domains of the real, the actual and the empirical... By constituting an ontology based on the category of experience, as expressed in the concept of the empirical world, and mediated by the ideas of the actuality of the causal laws and the ubiquity of constant conjunctions, three domains of reality are collapsed into one" (Bhaskar, 2008, p. 46).

As mentioned above, scape has a naturalist origin. Then, scape in this approach implies objection. In fact, part of the misunderstandings about urban landscape refers to the point that urban landscape has been evaluated by natural science (Blaikie, 2007; Chalmers, 2013). In this situation, urban landscape was considered as the visual elements and dimensions (Bell, 2012; Carmona et al., 2003; Cullen, 1961; Krier \& Rowe, 1979). In this approach, urban landscape has an inductive logic, it is also titled such as landscape and townscape. Zecavat introduces "view" as the visual part of urban landscape (Zekavat, 2006).

However, as the inductive approach was challenged more, the concept of urban landscape also changed. Critical rationalism developed by Popper believes that "Nature and social life are regarded as consisting of essential uniformities, i.e., patterns of events. It is the aim of science to discover these uniformities, to find universal statements that are true because they correspond to the facts of nature, or more correctly, to descriptions of observed states of affairs. However, the use of the senses is rejected as secure foundation for scientific theories" (Blaikie, 2000, p. 106). In this paradigm, theories

ACE, 16 (46) CC BY-ND 3.0 ES | UPC Barcelona, España | Redefining Urban Landscape regarding Scientific Realism Philosophy of Science. DOI: http://dx.doi.org/10.1080/ace.16.46.9202 
are created to explain observations rather than being concluded from them. The important study of Lynch about legibility could be categorized in this paradigm. Golkar introduces an urban landscape called perceptual/ contextual. He believes that this scape is the result of critical review of modern architecture and urban design (functional urban design). In his point of view, post-modern theories such as phenomenological studies and environmental perception studies lead to the emergence of perceptual or phenomenological aesthetic. Lynch, Appleyard, Lang, and Nasser are categorized in this group as he points out (Golkar, 2006). Urban landscape has a deductive logic in this paradigm. Lynch used a few concepts - place legibility - for better understanding of the built environment for its inhabitants. He distinguished the elements of townscapes in five categories: paths, edges, districts, nodes, and landmarks. To understand the image of the city is similarly having a grasp of townscape (Gurer, 2012, p. 1420).

These two mentioned approaches have their own ontological and epistemological bases but also have some similarities. "The inductive and deductive strategies adopt the "realist" ontology. They assume that social phenomena exist independently of both the observer and social actors" (Blaikie, 2000, p. 119) and it is the profession of urban designers to discover and describe the regular sequences or patterns in urban landscape. However, they are different in epistemology. One of these differences is the assumption about how it describes urban landscape and the other one is about how it explains urban landscape. "In the inductive strategy, the activity of observing, and the possibility of establishing the truth of a theory, is accepted uncritically, whereas in the deductive strategy, the inherent limitations of observations and the impossibility to know whether a theory is true are recognized. In the inductive strategy, faith is placed in "objective" procedures to arrive at the truth, while the deductive strategy involves the use of rigorous and critical evaluation of any theory that is proposed" (Blaikie, 2000, p. 119).

Golkar believes that urban landscape is influenced by urban design. He wrote that "mentioned concept has always been refined regarding the evolution of urban design” (Golkar, 2008, p. 40). Pakzad also believes that Lynch's image refers to mental image of a sightseeing or landscape rather than whatever being viewed" (Pakzad, 2006). Mansouri believes that subject-object duality would not be possible in defining urban landscape and subsequently, he believes that urban landscape is not a separate object from human. He introduces physic as whatever object that is independent of human, and morphology is the science which studies it (Mansouri, 2004).

Landscape urbanism has been proposed in the last decades as an interdisciplinary context mainly indebted to landscape architecture and urban design. The first time that the term "Urban Landscape" was used internationally was in the "Recommendation on the Safeguarding of the Beauty and Character of Places and Landscapes" (UNESCO, 1962). In 1996, Waldheim (1996) proposed landscape urbanism as a description of an emerging model for landscape architecture and urban design. In this point of view, landscape is considered as central emphasis on urban development (Faizi \& Razzaghi, 2008). Since 2013, European Union has proposed "border scape" regarding serious social, economic, cultural, and geographic changes during last three decades, and it studies conceptual differences of borders. It points out to a paradigmatic shift in sciences, especially social sciences (EU's 7th Framework Programme for Research and Technological Development, 2016). Teimouri remarks three theories in investigating urban landscape (Figure 2, 3, 4):

- Urban landscape is an inherent character of physic of city, and it is independent of human as observer (Figure 2).

- Urban landscape is a subjective matter created by observers, and it is not related to the structure of physical environment (Figure 3). 


\section{ACE Architecture, City and Environment}

-ISSN 1886-4805

- Urban landscape is a phenomenon or event being produced during commuting between physical properties of environment on the one hand, and cultural symbols and mental capabilities of observers on the other hand (Figure 4) (Taimouri, 2007).

Figure 2. Urban landscape is considered as an independent issue from human as observer
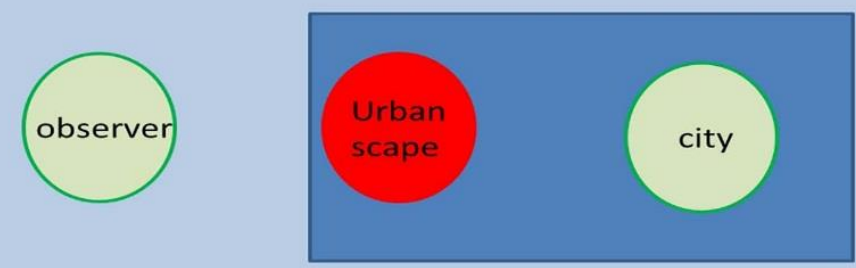

Source: prepared by the authors

Figure 3. Urban landscape as a subjective matter

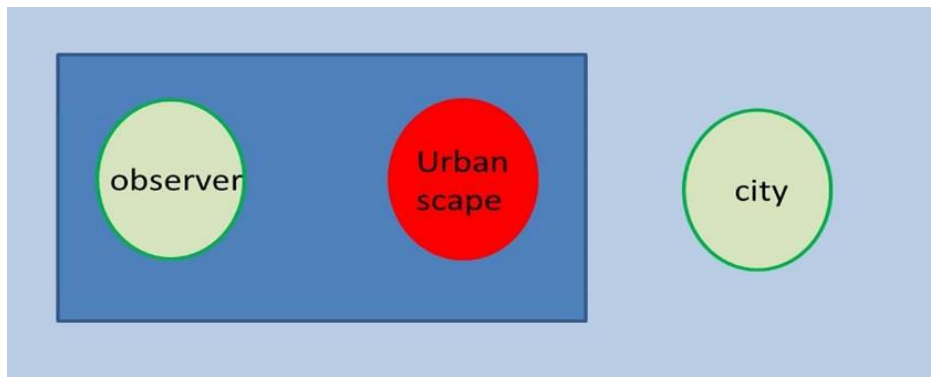

Source: Prepared by the authors

Figure 4. Urban landscape is a phenomenon or event between physical properties and cultural symbols

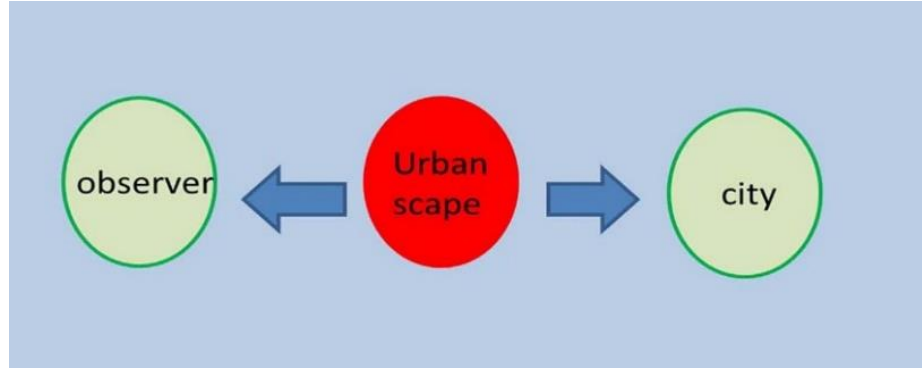

Source: Prepared by the authors

In the two mentioned paradigms, landscape perception mainly emphasizes natural visual patterns and image of observer. In these two paradigms, landscape was investigated as a personal phenomenon; and observer is always considered. In the case semantic pattern is discussed, it is only about the personal scheme of observer. However, the observer is never separated from his society. As Lefebvre "wants to investigate the instinctive, the emotional and "irrational" as social facts" (Goonewardena, Kipfer, Milgrom, \& Schmid, 2008, p. 36). In his point of view, the symbol constructs the social imagination, which is different from personal imagination. Then, there is a clear distinction between philosophical function of imagination and social function of symbol (ibid). It seems that many of landscape theories are influenced by Hegelian and Marxian dialectic. Some dialectics such as image-landscape, physical-semantics, and form-function are introduced regarding this dialectic.

ACE, 16 (46) CC BY-ND 3.0 ES | UPC Barcelona, España | Redefining Urban Landscape regarding Scientific Realism 6 Philosophy of Science. DOI: http://dx.doi.org/10.1080/ace.16.46.9202 
These two paradigms are criticized by scientific realism and especially its constructivist realism branch. Positivism paradigm was challenged by different social scientists regarding science revolutions (Kuhn, 2012). Bhaskar also talks about three traditions in science philosophy: empirical realism, transcendental idealism, and critical realism. In his point of view, empirical realism does not consider the social character of science recognition (Bhaskar, 2013). Positivism paradigm mainly ignores the underneath structures making phenomena (Hassard, 1993; Sayer, 1999). Bhaskar also mentions the trans-phenomenality character of phenomena referring to underneath structure (Archer, Bhaskar, Collier, Lawson, \& Norrie, 2013; Bhaskar, 2013).

"In the realist ontology, the ultimate objects of scientific enquiry are considered to exist and act independently of scientists and their activity. A distinction is made between the domains of the empirical, the actual and the real: the empirical domain consists of events that can be observed; the actual domain consists of events whether they are observed; and the real domain consists of the structures and mechanisms that produce these events. It is the ontology of intransitive structures and mechanisms that are distinguished from transitive concepts, theories and laws that are designed to describe them. These structures and mechanisms are the real essences of things that exist in nature; such essences being their power or tendency to produce effects that can be observed" (Blaikie, 2000, p. 108) (Figure 6).

Figure 5: The relation of three domains with mechanism, events, and experiences

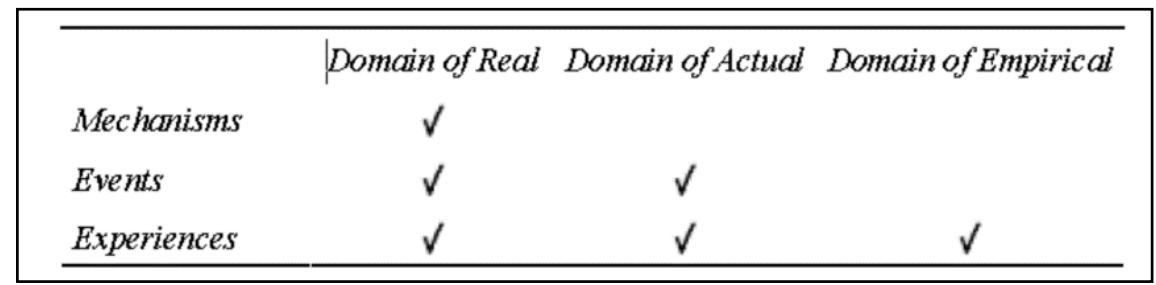

Source: (Bhaskar, 2008, p. 47)

Bhaskar believes that empirical realism reduces ontology to epistemology which is also human based (Bhaskar, 2013). In his point of view, "Empirical realism depends upon a reduction of the real to the actual, and of the actual to the empirical" (Bhaskar, 2008, p. 49). Positivism approach of urban landscape explains landscape through the fixed link between phenomenon and events. However, scientific realism believes that finding these rules is only the beginning of a scientific research and, after that, it should find the structure and mechanism creating this relationship (Table 1). Figure 5 shows the reflection of each paradigm on the understanding urban landscape.

Figure 6. Philosophy of science and urban landscape

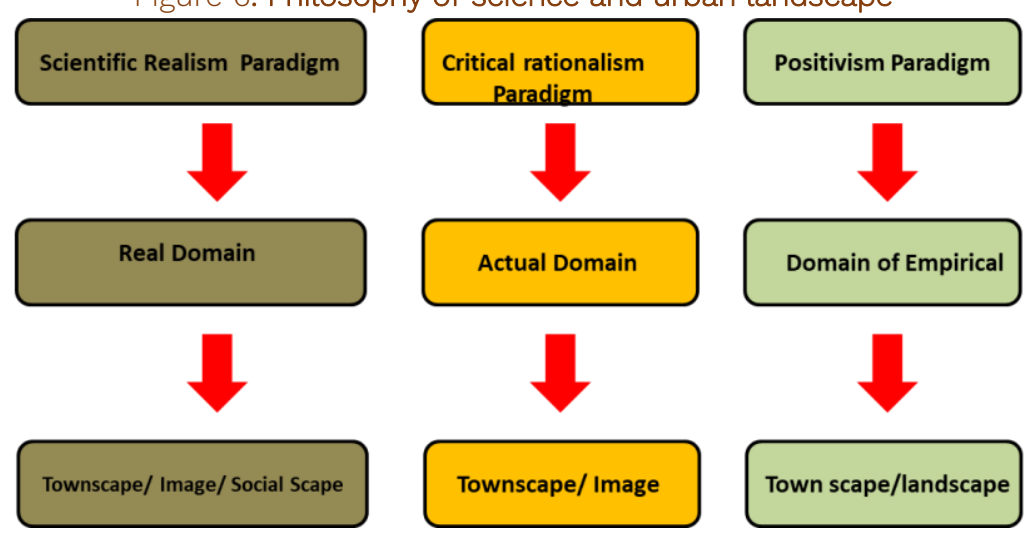

Source: Prepared by the authors.

ACE, 16 (46) CC BY-ND 3.0 ES | UPC Barcelona, España | Redefining Urban Landscape regarding Scientific Realism Philosophy of Science. DOI: http://dx.doi.org/10.1080/ace.16.46.9202 
Tabla 1. Different paradigms and their reflection on urban landscape

\begin{tabular}{|c|c|c|c|}
\hline Paradigm & Ontology and Epistemology & Reflecting on Urban landscape & $\begin{array}{l}\text { Urban } \\
\text { landscape } \\
\text { theorisian }\end{array}$ \\
\hline Positivism & $\begin{array}{l}\text { - neutrality of observer in } \\
\text { recognizing nature and environment } \\
\text { - } \quad \text { Only that which can be } \\
\text { observed, that is experienced by the } \\
\text { senses, can be regarded as real and } \\
\text { therefore worthy of the attention of } \\
\text { science } \\
\text { - } \\
\text { senses Recognition through human } \\
\text { - } \\
\text { observations or data } \\
\text { - Researchers undermines his } \\
\text { assumptions }\end{array}$ & $\begin{array}{l}\text { - urban landscape was } \\
\text { considered as the visual } \\
\text { elements and dimensions } \\
\text { • } \quad \text { urban landscape } \\
\text { embodies objectivity } \\
\text { - } \quad \text { urban landscape exists } \\
\text { separately from observer and } \\
\text { social interaction, and it is urban } \\
\text { specialist duty discovering and } \\
\text { describing it } \\
\text { - Observation and } \\
\text { verification of a theory accepted } \\
\text { undoubtedly. } \\
\text { - } \quad \text { Urban landscape has } \\
\text { inductive logic in this approach } \\
\text { - } \quad \text { Urban landscape titled } \\
\text { such as urban landscape, } \\
\text { townscape, and landscape. }\end{array}$ & $\begin{array}{l}\text { Gordon } \\
\text { Cullen, Krier }\end{array}$ \\
\hline $\begin{array}{l}\text { Critical } \\
\text { Rationalism }\end{array}$ & $\begin{array}{l}\text { - the use of the senses is } \\
\text { rejected as secure foundation for } \\
\text { scientific theories } \\
\text { • Nature and social life are } \\
\text { regarded as consisting of essential } \\
\text { uniformities } \\
\text { - } \quad \text { theories are created to } \\
\text { explain observations rather than being } \\
\text { concluded from them } \\
\text { - The inductive approach } \\
\text { includes the exact and critical } \\
\text { assessment of all proposed theories. }\end{array}$ & $\begin{array}{l}\text { - } \\
\text { - } \\
\text { inderban landscape exists } \\
\text { observer and social actors and } \\
\text { urban specialist should discover } \\
\text { and describe its regularities. } \\
\text { - Intrinsic limitations of } \\
\text { observation are accepted } \\
\text { - Urban landscape is } \\
\text { known as "Image" }\end{array}$ & $\begin{array}{l}\text { Lynch. } \\
\text { Appelyard, } \\
\text { Lang, Ne }\end{array}$ \\
\hline $\begin{array}{l}\text { Scientific } \\
\text { Realism }\end{array}$ & $\begin{array}{l}\text { - the ultimate objects of } \\
\text { scientific enquiry are considered to } \\
\text { exist and act independently of } \\
\text { scientists and their activity } \\
\text { - A distinction is made } \\
\text { between the domains of the } \\
\text { empirical, the actual and the real } \\
\text { • Explaining obsevable } \\
\text { phenomena regarding underneath } \\
\text { structure. } \\
\text { - It considers a time and place } \\
\text { domain for theories. } \\
\text { - } \\
\text { between transitive and intransitive } \\
\text { objects of science. Transitive objects } \\
\text { are the concepts, theories and models } \\
\text { that are developed to understand and } \\
\text { explain some aspects of reality, and } \\
\text { intransitive objects are the real } \\
\text { entities and their relations that make } \\
\text { up the natural and social worlds. } \\
\text { • Causual relations are } \\
\text { regarded as powers or tendencies of } \\
\text { things that interact with other } \\
\text { tendencies such that an observable } \\
\text { event may or may not be produced } \\
\text { and may or may not be observed. }\end{array}$ & $\begin{array}{l}\text { - Urban landscape is not } \\
\text { the only visual things, but it is } \\
\text { also including its producing } \\
\text { mechanism. } \\
\text { • Urban landscape } \\
\text { embodies social dimension and } \\
\text { does not only refer to the } \\
\text { observer imagination. } \\
\text { - } \quad \text { Many of observers' } \\
\text { unconscious originates in social } \\
\text { imagination in contrast to } \\
\text { deductive approaches } \\
\text { introducing observer's } \\
\text { understandings as "image". } \\
\text { - Some aspects of urban } \\
\text { landscape could be observed or } \\
\text { not. } \quad \text { Urban landscape } \\
\text { - production is different for each } \\
\text { place. Different events in } \\
\text { different places might produce } \\
\text { same or different urban } \\
\text { landscape. }\end{array}$ & $\begin{array}{l}\text { Henri } \\
\text { Lefebvre, } \\
\text { critical } \\
\text { thought }\end{array}$ \\
\hline
\end{tabular}




\section{Urban landscape production}

City and urban landscape embody various actions of city. Exact perception of urban landscape needs to be released from usual "objective-subjective" duality. This duality makes urban landscape a certain fact or reduces it to a decorative item. However, urban landscape represents the way citizens think, behave and build. In fact, it is a process which is finally produced as a social production. This research is going to emphasize that urban landscape is not separated from the fate of urban space. Thus, better perception of urban landscape requires better understanding of urban space. Otherwise, the viewpoint that looks at urban landscape as a physical aspect of city is a decreasing one, and it could not clarify all aspects of urban landscape completely. In this point of view, urban landscape has also a social dimension in addition to the objective and subjective dimensions. This paper tries to redefine urban landscape with Henri Lefebvre's notions.

\subsection{Production of space theory}

"(Social) space is (social) product" (Lefebvre, 1991, p. 26). Lefebvre believes that space is social and consequently political. "It involves assigning more or less appropriated places to the social relations of reproduction; namely, the bio-physiological relations between the sexes, the ages, the specified organization of the family, and the relations of production; namely, the division of labor and its organization" (Goonewardena, 2012, p. 186). In his point of view, space does not exist. Space "in itself" can never serve as an epistemological starting position" (Goonewardena et al., 2008, p. 28).

From this point of view, the terms such as "townscape" and "urban landscape" are not so obvious because their assumptions on space are considered. He believes that time and space are not a priori subjects, and they are only comprehensible in a specific context. "As early as 1939, Lefebvre had described geometric space as abstractive, and had likened it to clock time in its abstraction of the concrete" (Elden, 2004, p. 187). There is a difference between our imagination of space- abstract, subjective, geometric- and our perception about that- concrete, physical and materialistic. Lefebvre believes that abstract space is by violence and war. In his point of view, such space is politically established by states. In (Table 2) the dimensions of this theory are explained.

Table 2. Paradigms, their principals, and urban landscape

\begin{tabular}{|c|c|c|}
\hline $\begin{array}{l}\text { Perceived space. } \\
\text { (Spatial practice) }\end{array}$ & $\begin{array}{l}\text { Conceived space. } \\
\text { (Representation of space) }\end{array}$ & $\begin{array}{l}\text { Lived space. } \\
\text { (Space of representation) }\end{array}$ \\
\hline $\begin{array}{l}\cdot \text { Material } \\
\text { dimension of activity } \\
\cdot \quad \text { Perceived by } \\
\text { five senses } \\
\cdot \quad \text { Concrete } \\
\text { aspect of space }\end{array}$ & $\begin{array}{l}\text { - Abstract space } \\
\text { - } \quad \text { Paper-based and three } \\
\text { dimensions of drawing } \\
\text { - In the level of dialogue and } \\
\text { discourse } \\
\text { - } \quad \text { Descriptions, definitions, and } \\
\text { especially scientific theories } \\
\text { planning Architecture and geographical } \\
\text { - The space belongs to } \\
\text { companies, planners, and politicians. }\end{array}$ & $\begin{array}{ll}\text {.. } & \text { Symbolic dimension of space } \\
\cdot & \text { Referring to a dominant } \\
\text { power, logos, state, feminine or } \\
\text { masculine principal } \\
\text { - } \quad \text { An intermediate which a body } \\
\text { interacts with other bodies through it. } \\
\text { - } & \text { Social relations } \\
\text { - } & \text { Lived matters } \\
\text { - } & \text { Social memories } \\
\text { - } & \text { Spatial experiences }\end{array}$ \\
\hline
\end{tabular}

Source: Prepared by the authors.

An important change has been happening since 1970. A change which, according to Chomsky (2012) and Harvey (2011), has been a change towards deindustrialization and de-development and has caused industrial production to move beyond borders. Due to this, production has shifted towards financial intervention. Naturally, cities have been the base for all these changes and what Chomsky calls 'vicious cycle' has corrupted urban cores. 
In the process of commodification, cities have been degraded down to brands and, in other words, 'exchange value' has replaced 'use value'. To attract tourists and investors, cities have become delusive phenomena. Knox (2010) believes that, in this period, globalization has caused cities to be dependent on each other more than ever. The levels of globalization have increased among urban populations...along with structural economic changes, globalization has also increased the competition among cities for the purpose of fundraising. As a result, design has turned out to be an important element in the competition between cities in the post-industrial economy era. Gospodini (2002) also believes that nowadays urban space quality has turned out to be a pre-requisite of the economic development of cities and urban design has accepted a new role as a tool for economic development while, for several centuries, urban environment quality was a result of the economic development of cities. In this line, klingmann taik about brandscape (Klingmann, 2007) and Julier coin the urban designscape term (Julier, 2005). These evolutions lead to "creative destruction" which Austrian economist, Schumpeter mentioned regarding Marx writings. This term has been referred a lot since 1950s. creative destruction describes the "process of industrial mutation that incessantly revolutionizes the economic structure from within, incessantly destroying the old one, incessantly creating a new one (Schumpeter, 1994, p. 82-83). Harvey also refers to this concept as a critical solution of neoliberalism for economic development (Harvey, 2007; 2011). In his point of view, creative destruction leads to ubordinate classes to dominant ones and from poorer to richer countries. Therefore, economy keeps intertwining cities with global issues day by day and, in this respect, a competition for fundraising among cities has come about which can threaten the 'local dimension' and identity of cities. Multinational corporations, insurance companies, large-scale offices etc. are land uses which function on a level far beyond their city and sphere of influence.

These structures, due to their nature, possess a style, which influences audiences and attracts investors and tourists. Diener et al., criticize the notions regardin globalization as a homogenization process. In his point of view "The process of globalization is marked by contradictory processes of homogenization and differentiation...leads to specifically individual urban situation and configuration" (Diener, 2015, p. 288).

Another feature of this kind of architecture is that it is built using pioneering technology, is often in contrast, and even clash with its background to attract more attention. Such structures deteriorate the skyline and change the urban sky together and the urban land into the goods of their trade. Additionaly, such land uses try to control spaces and make them exclusive (Madanipour, 2007, 2010; Carmona, 2008, Knox, 2010). In fact, urban globalization affects and even scares all aspects of our life. "Recent delocalization of life has unfortunately implied a sort of indolence to renew territirial theories. An indolence well represented by the fact that what has animated the city of the last twenty years can be summed up in the FIRE acronym, which is, Finance, Insurance, Real'State and Enterorise" (Acebillo and Schmid, 2012, p. 18). As a result, a 'mirage city' is formed. 'Mirage city' stands for the dominance of a powerful minority over urban spaces and marginalizing the majority which lacks the influence and wealth to affect urban changes.

\subsection{Dimension of urban landscape production}

Regarding Lefebvre's dialectic and his space production theory and the relation of urban landscape and urban space, this dialectic could be developed to urban landscape. According to Lefebvre's production space, urban landscape should be studied with two main approaches: phenomenological and semiotic approach (Figure 7).

ACE, 16 (46) CC BY-ND 3.0 ES | UPC Barcelona, España | Redefining Urban Landscape regarding Scientific Realism 10 Philosophy of Science. DOI: http://dx.doi.org/10.1080/ace.16.46.9202 
Figure 7. Approaches for studying urban landscape

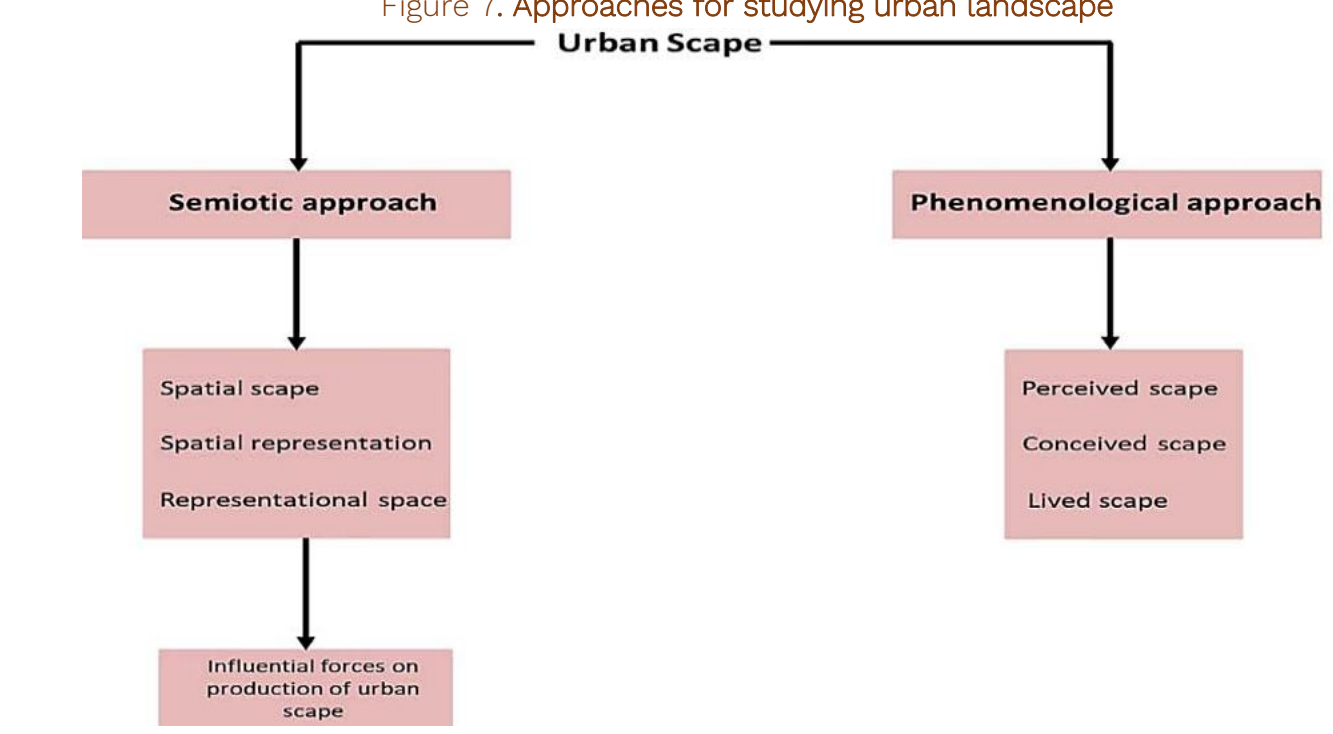

Source: Prepared by the authors

There is a phenomenological approach in which different scapes could be defined: perceived scape; conceived scape and lived scape (Figure 8). This understanding of scape helps urban landscape not to be considered an abstract matter anymore; rather, it would be also considered an "abstractconcrete" concept. Moreover, urban landscape should not be reduced to conceived scape, which is the imagination of architects, urban planners, urban development planners, managers, and influential persons about cities. However, it is a phenomenon embodied in time and is always being reproduced. Every time urban space is being used, consequently, urban landscape improves in the users' mind. This is the field having symbol and meaning. Then, it could be said: "Urban landscape is neither subject nor object, however, it is the emergence of social reality which is always being perceived dynamically in a phenomenological and semiotic relationship, and it is also reproduced continuously".

Figure 8. Phenomenological dimension of urban landscape

\section{Perceived by senses}

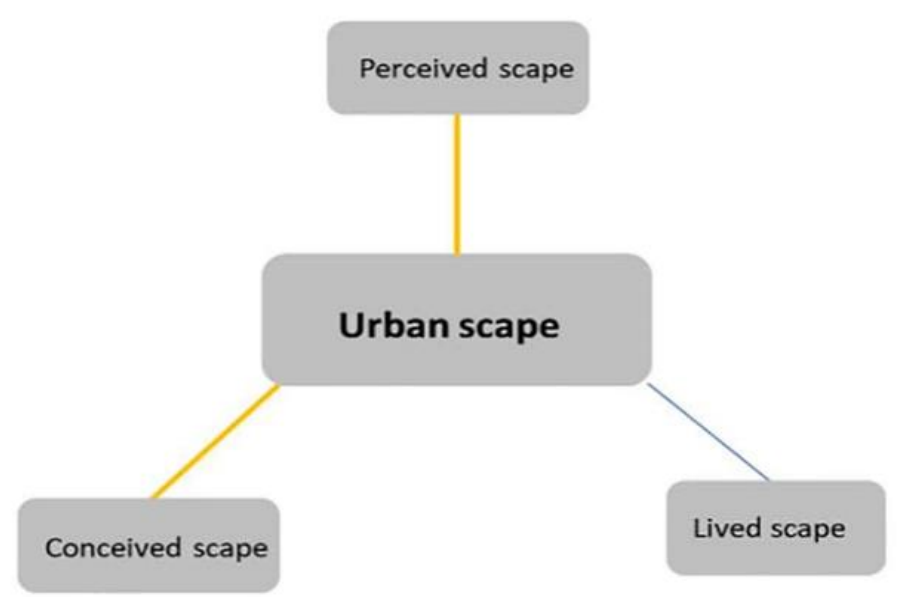

A priori imagination of each actor of space

Direct experience of being in space

Source: Prepared by the authors.

ACE, 16 (46) CC BY-ND 3.0 ES | UPC Barcelona, España | Redefining Urban Landscape regarding Scientific Realism 
If every society produces its own space, then, it likely presents its real existence in such space. However, if it could not produce its own space, it would be changed into a strange existence; a sort of weird abstract that could not escape from ideological and also cultural atmosphere of time (Figure 9).

Figure 9. The relationship of urban landscape, city, and observer

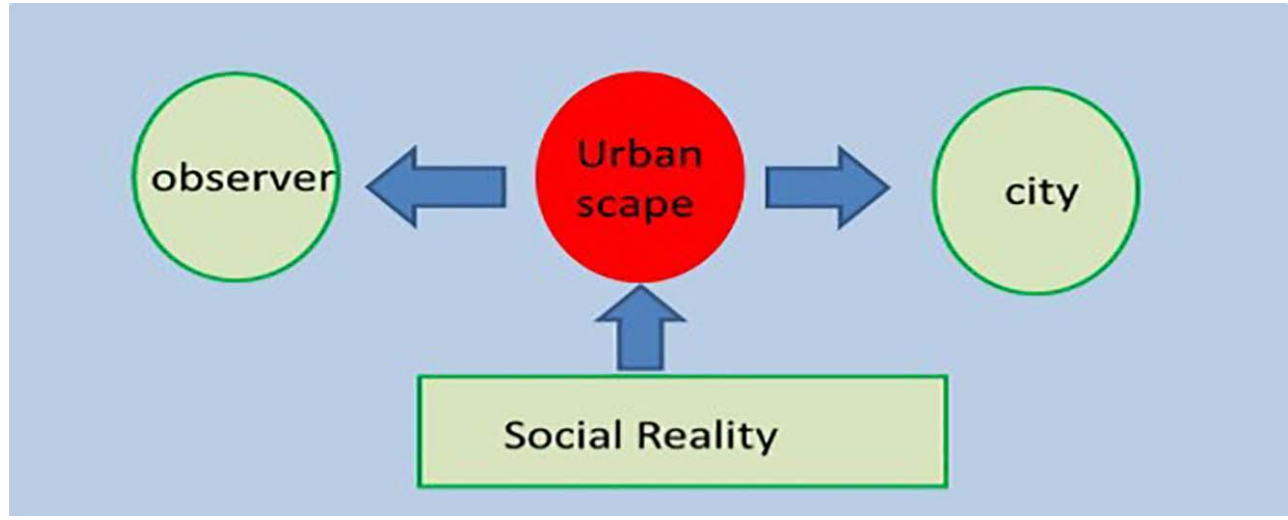

Source: Prepared by the authors.

Lefebvre believes that space should be considered the product and the process simultaneously indicating social practices. "Space is the production of ideological, economic, and political (power territory) forces trying to indicate, control and regulate the actions occurred in it (Zieleniec, 2007, p. 61). Lefebvre explains that space is such a hegemonic tool being used by dominant classes for reproducing their domination: "(Social) space is a (social) product ... That in addition to being a means of production, it is also a means of control, and hence of domination of power" (Lefebvre, 1991, p. 26).

\subsection{Influential forces on urban landscape}

Lefebvre looks at space with twofold approaches: phenomenological and semiotic. In each approach, he reaches three moments of production by using a new definition of dialectic. It seems that this dual approach has been forgotten, or maybe Lefebvre could not explain it clearly. Moreover, the spatial translation of semiotic approach is not so explicit, and it remains abstract. The semiotic approach, which Lefebvre talks about, originates from language theory and it is also influenced by Nietzsche's language theory. In this theory, Lefebvre refers to two classic dimensions of language (Syntatic and Paradigmatic) and he adds a third dimension (symbolic) to them. The dimension "deals with the formal rules of combination that determine the relationship between the signs, their possible combinations, sentence structure, and syntax" (Goonewardena et al., 2008, p. 35). The paradigmatic refers to substitution. "This operation implies the possibility of substituting one term for another that is equivalent to the first from one point of view, and different from it when viewed from another angle" (ibid). The symbolic dimension is also charged with images, emotions, affectivity, and connotations.

Corresponding to these three aspects, Lefebvre proposes spatial practice (analogous to syntagmatic dimension), representation of space (analogous to paradigmatic dimension) and spaces of representation (concerning symbolic dimension). However, this classification remains ambiguous. For example, it is not noticeably clear when space of representation is created, or the boundaries between these three are not well-defined, and the relation between semiotic and phenomenological dimension is not so clear. This paper tries to make them clearer about the urban landscape mechanisms introduced in scientific realism (and especially its constructivist branch) and with "influential forces on urban evolutions". 
There are various theories considering factors that shape cities (Bentley, 2004; Carmona et al., 2003; Cuthbert, 2008; Jacobs, 1969; Kostof, 1992; Lynch, 1984; Morris, 2013; Mumford, 1961; Sitter, 2013; Kostof, 1991). In fact, cities have been shaped differently according to their citizens' needs. Madanipour emphasizes the human reason in shaping cities. "Reason is the human faculty that, through intuition and calculation, makes judgments about, and provides accounts for, what to believe and how to act" (Madanipour, 2007, p. 3).

Cities have transformed under the influence of various factors such as natural and climatic situations, economic forces, political and administrational forces, and socio-cultural forces. "Directing the evolutions of cities requires suitable understanding of the way these forces interact in urban spaces" (Soltani \& Namdarian, 2010). In (Table 3) these factors are called force, and they affect cities in different ways.

Then, the composition of these mentioned forces makes different shapes for cities. In this line, city could be considered a text, which various forces direct their evolutions, through text and meta text. Figure 10 displays the schematic relationship of these forces. This figure explains that there are some forces dominating specific points. In this regard, the important spaces are the places where plural forces exist. Consequently, the most important space is the place in which most forces discourse. According to the syntax principal of language theory, the influential forces could be present beside each other and follow "this force- and- this force- and- this force" composition. For example, "natural-social-political" composition shows the space in which natural force is crucial. Spaces like urban hills having historical monumental, such as Acropolis in Athena, are examples of this composition.

Table 3. Forces and their impact on cities

\begin{tabular}{|c|c|c|}
\hline $\begin{array}{l}\text { Influential forces on urban } \\
\text { evolutions }\end{array}$ & Description & How the forces affect cities \\
\hline Zeitgeist & $\begin{array}{l}\text { The product of inhabitant's } \\
\text { experiences, regarding climate } \\
\text { situation and social values }\end{array}$ & $\begin{array}{l}\text { Emergence of organic zone } \\
\text { Harmony of texture and values and } \\
\text { natural characters }\end{array}$ \\
\hline Administrational force & $\begin{array}{l}\text { Having plans and design, imposed } \\
\text { from top to bottom }\end{array}$ & $\begin{array}{l}\text { Master and detailed plans, grid } \\
\text { network, building certificate from } \\
\text { municipality or the other } \\
\text { administrational organs, }\end{array}$ \\
\hline Economic Force & $\begin{array}{l}\text { Attention to relative advantages of } \\
\text { places, irreverence to master plan } \\
\text { propositions, }\end{array}$ & $\begin{array}{l}\text { Inharmonic and chaos in built } \\
\text { environment, skyline disorder, } \\
\text { disparate townscape, sprawl of main } \\
\text { elements and the effect of capital on } \\
\text { urban development }\end{array}$ \\
\hline Political force & $\begin{array}{l}\text { Based on power of central } \\
\text { government, symbol of glory of } \\
\text { government }\end{array}$ & Emergence of dual texture \\
\hline Social Force & $\begin{array}{l}\text { Attention to social values and long- } \\
\text { term expedients of society }\end{array}$ & $\begin{array}{l}\text { Organizing social society and creating } \\
\text { social formation, improving social } \\
\text { associations, creating sense of } \\
\text { belonging. }\end{array}$ \\
\hline
\end{tabular}

Source: Prepared by the authors.

In this situation, dominant landscape is natural scape and vista, and view corridors play important roles in them. If that mentioned composition experiences some changes in its arrangement, then syntax would happen. In the composition explained as an example, following small movement, a new composition such as "Political-Social-Natural" would be created. Saad Abad Palace in Tehran, Iran is an example of this composition in which political force is in priority. From phenomenological point of view, dominant landscape of this composition is lived scape which is important in social life. Perceived scape is not as important as previous arrangement. However, substitution principal in language theory analyzes different forces instead of each other. 
In fact, this principal uses the arrangement of "this force- or- this force- or- this force". In the case this principal affects the "natural-social-political" composition, it might change into "economic-socialpolitical", and its example is the traditional Bazzar (Figure 10).

Figure 10. Three semiotic dimensions of urban landscape

\section{Symbolic dimension}

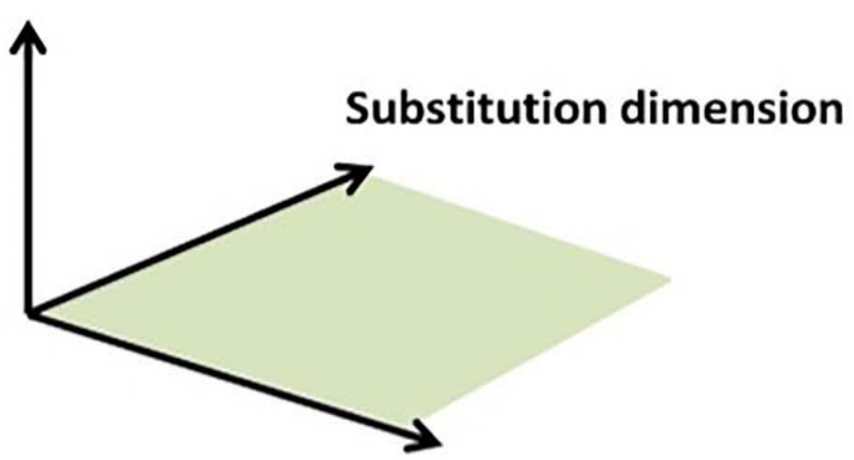

Syntax dimension

Source: Prepared by the authors.

Producing forces are the factors that could set aside material and activity elements of space (syntax dimension); they could also substitute one force instead of the other (substitution dimension); these forces could also define the social imagination (symbolic dimension). In other words, producing forces could simultaneously create different aspects of semiotic dimension and refer to the relationship of this dimension with phenomenological ones (Figure 11).

Figure 11. Influential forces on urban landscape

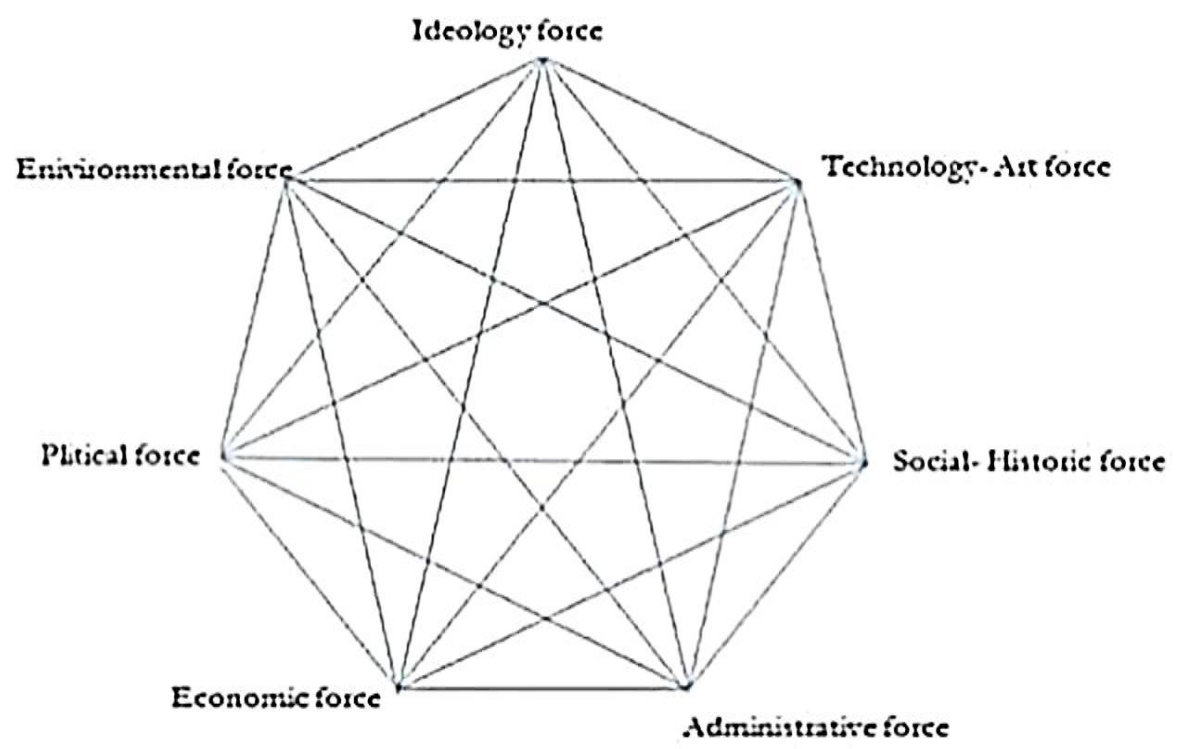

Source: Prepared by the authors.

ACE, 16 (46) CC BY-ND 3.0 ES | UPC Barcelona, España | Redefining Urban Landscape regarding Scientific Realism 
Urban landscape would be at its harmony and equilibrium while the dialectic of forces releases urban space from the domination of one or some limited forces. Nowadays, the fate of urban spaces is mostly indicated by economic-political forces. They could send other forces out of circle regarding their economic potential and their influence in decision-making organs. Consequently, "exchange value" is increasingly important in urban evolutions rather than "consumption value".

\section{Results}

Regarding the definition of urban landscape "as a social reality", it is neither limited to physical aspects nor reduced to decoration matter anymore. Theoretical framework codification for urban landscape needs considering the "why" and "how" of its production in addition to "what" urban landscape is. Urban landscape could not be separated from urban space production. Then, understanding influential forces of urban evolutions is necessary for improving urban landscape. On the other hand, urban landscape is always considered a complex or it is more obvious than whatever it could be discussed. It is due to various understandings of urban landscape that different definitions are presented.

Based on Lefebvre's production space and the relation of space and scape, some criteria could be introduced. These criteria embody physical, mental, and social aspects of urban landscape. Influential forces in urban landscape and the criteria of urban landscape affect each other. The dialectic presence of forces in urban spaces also affects the phenomenological dimension of urban landscape. For example, vista, which belongs to, conceived scape and consequently phenomenological dimension, acquires a symbolic aspect whenever affected by ideological force, and it would be part of lived scape. That means there are influential forces, which create various perceived, conceived, and lived scape or lead to a phenomenological relationship between these scapes.

Semiotic dimension is corresponding with one of realism scientific principles. "Causal relations are regarded as power of tendencies of things that interact with other tendencies such that an observable event may or may not be produced and may or may not be observed" (Blaikie, 2000, pag. 109). The urban landscape producing forces could create multiple scapes through different compositions, or they could increase or decrease the importance of each scape.

For example, nowadays cities have relatively similar scapes due to economic force: locating skyscrapers in the important point of city, drawing attention, and influencing users, inhuman scale of spaces, land speculative, margining poor and middle classes, bypassing legal obstacles and usual controlling tools of urban plans are aspects of this scape. In this situation, if the production mechanisms of scape were not specified, any suggestion for changing the scape would be only codes and briefs, which do not have executive guarantees.

Table 4 shows urban landscape production factors and their indicators. It should be mentioned that the urban landscape indicators emerge differently in various scales. In strategic scale, the important subject is area, while in small scale and urban space, mixed use and activities are investigated.

Conceived scape is one, which is discussed by professionals, or it is also the imagination that people have about a city (even if they do not see it). When someone hears the name of city, an image will be created resulting from books, newspapers, and films he has experienced during his lifetime.

ACE, 16 (46) CC BY-ND 3.0 ES | UPC Barcelona, España | Redefining Urban Landscape regarding Scientific Realism 15 Philosophy of Science. DOI: http://dx.doi.org/10.1080/ace.16.46.9202 


\section{ACE Architecture, City and Environment}

e-ISSN 1886-4805

Table 4. Theoretical framework of urban landscape regarding "the production of space" theory and "influential forces

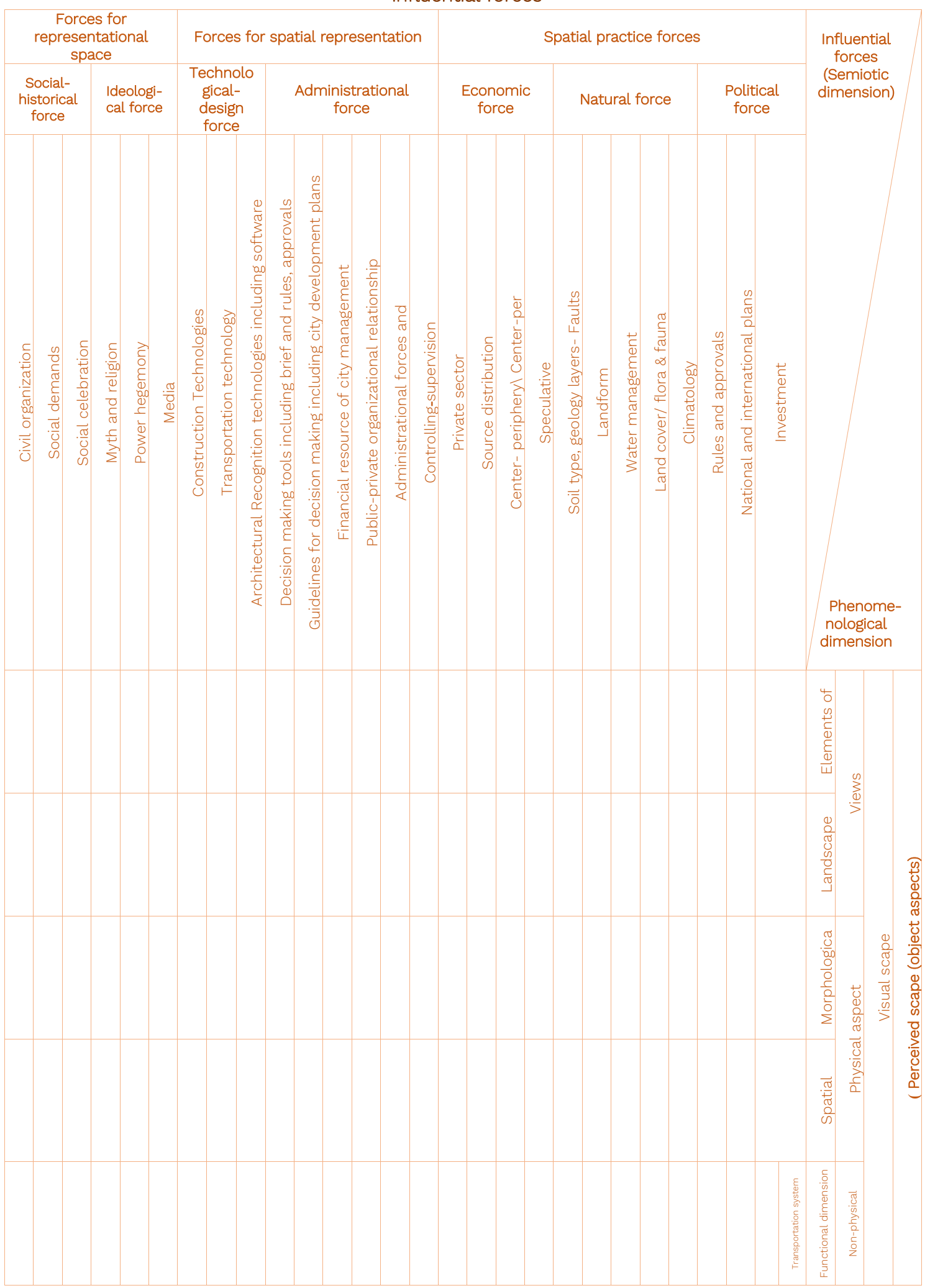

ACE, 16 (46) CC BY-ND 3.0 ES | UPC Barcelona, España | Redefining Urban Landscape regarding Scientific Realism 
ACE Architecture, City and Environment

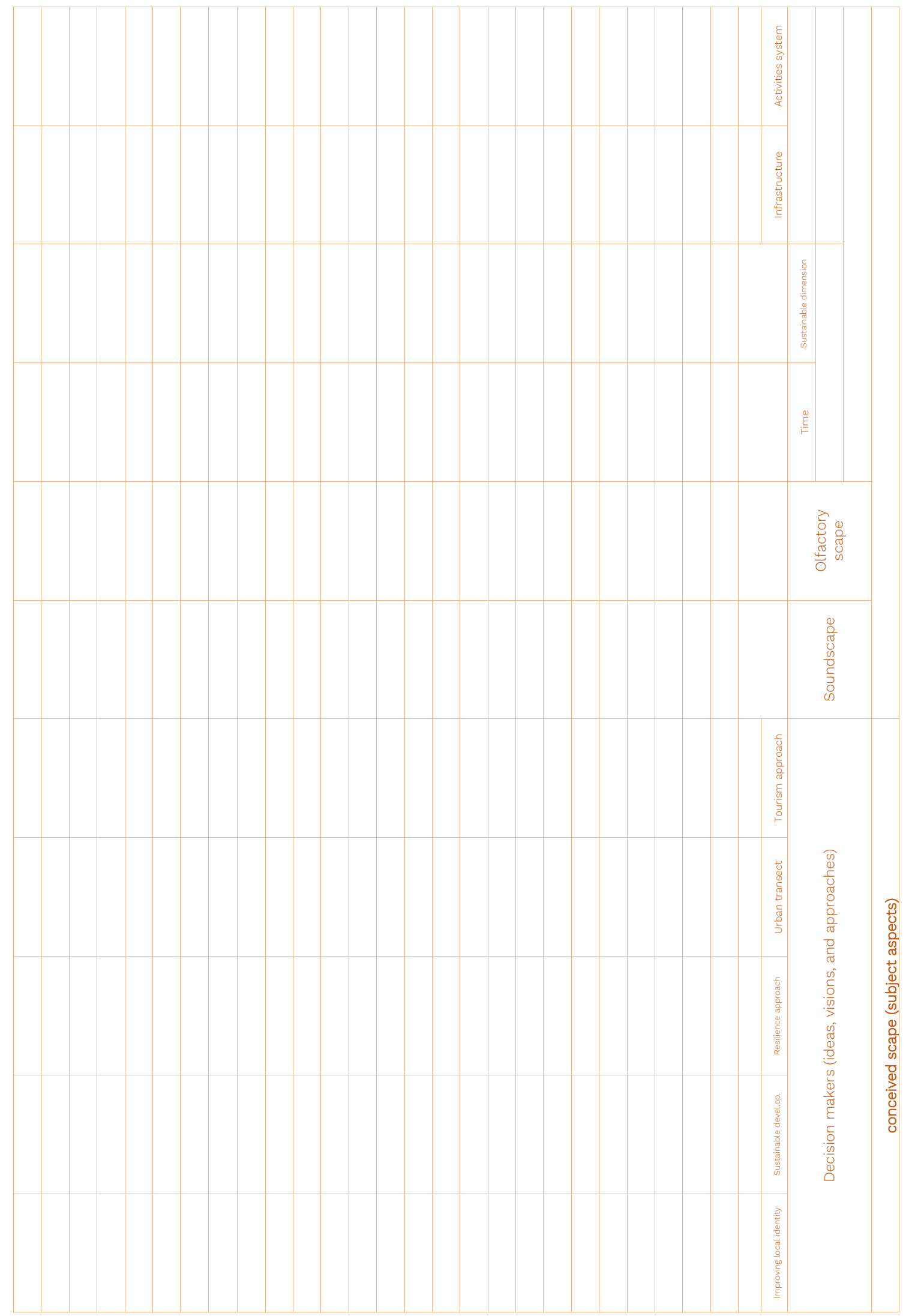




\section{ACE Architecture, City and Environment}

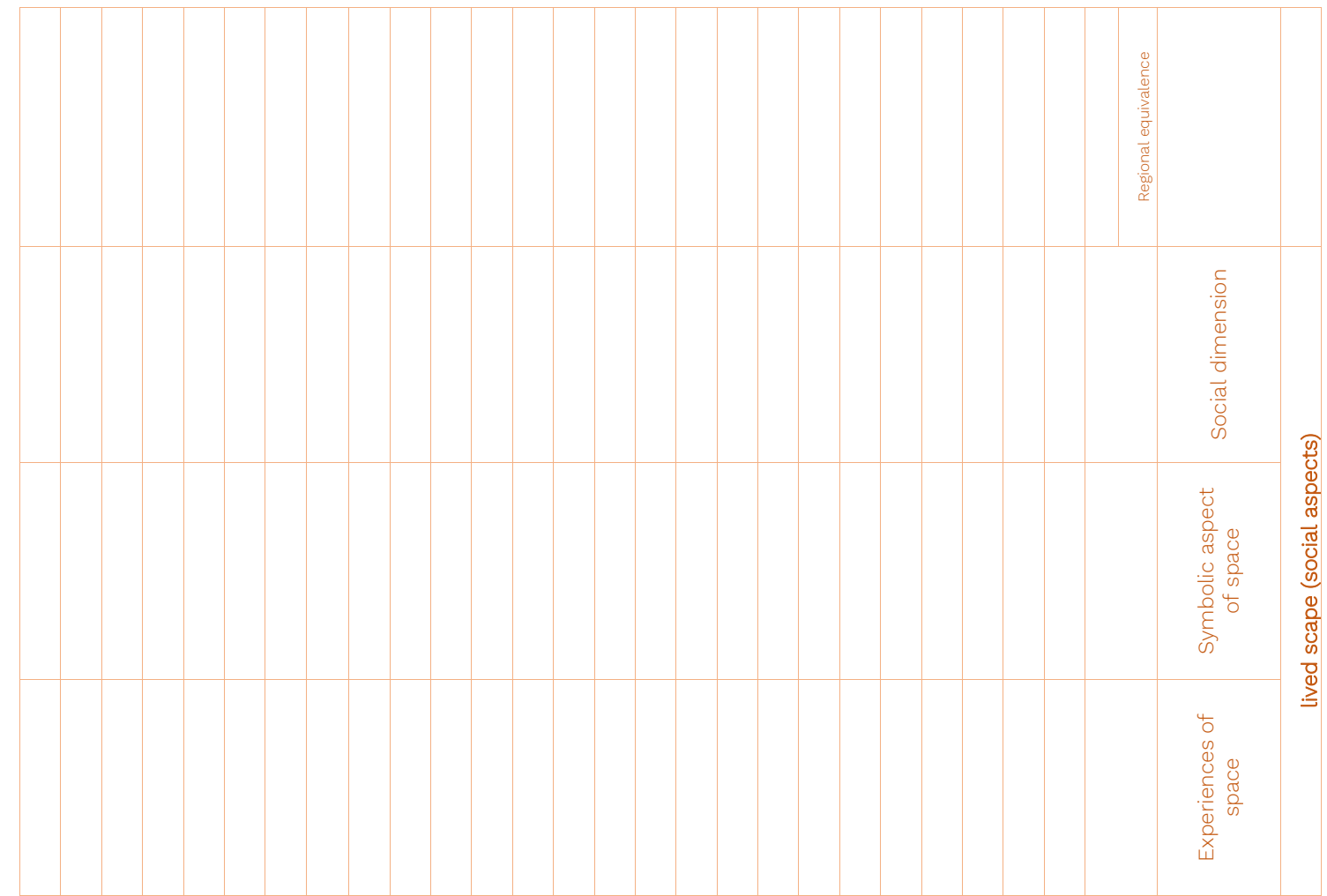

Source: Prepared by the authors.

\section{Conclusion}

Urban landscape of each city is the emergence of reality of that city being understood in a phenomenological-semiotic relation. It could not be reduced to an objective issue, neither is it subjective being shaped separate from objective one. In addition, urban landscape could not be reduced to phenomenological relation between subjective-objective dimensions.

Regarding Lefebvre's reading of phenomenological materialism and by using Lefebvre's production space theory and influential forces in semiotic dimension of urban landscape, a new theoretical framework could be suggested. With this new definition, urban landscape embodies all aspects of urban space production. Perceived scape includes those parts that are perceived by different senses and are not merely visual. Conceived scape is the one that decision-makers and different scientist experts have; lived scape also refers to symbolic and meaning aspects. However, these are not all the scapes. There are various forces directing these three mentioned scapes in the format of social practice forces, forces for representation of space, and forces for space of representation.

\section{Authorship}

The first author has developed the topic and has written the main structure of this paper. The second author has developed the idea according to Henri Lefebvre's writings. The third author has a key role in developing methodology. The fourth author is the supervisor of visiting research period of the the first two authors at UPC. He has an important role for developing the the paper and preparing the paper based on ACE guideline and also the edition process. 
Conflict of interests: The authors declare that there is no conflict of interest.

\section{Bibliography}

Acebillo, J., Jacques L. \& Schmid, C. (2012). Globalization of urbanity. Actar Publishers.

Aldrich, R. I. (1966). The Development of"-Scape". American Speech, 41(2), 155-157.

Antwi, S. K., \& Hamza, K. (2015). Qualitative and quantitative research paradigms in business research: A philosophical reflection. European Journal of Business and Management, 7(3), 217-225. https://www.iiste.org/Journals/index.php/EJBM/article/view/19543

Aliyu, A. A., Bello, M. U., Kasim, R., \& Martin, D. (2014). Positivist and non-positivist paradigm in social science research: Conflicting paradigms or perfect partners. J. Mgmt. \& Sustainability, 4, 79. DOI:10.5539/jms.v4n3p79

Archer, M., Bhaskar, R., Collier, A., Lawson, T., \& Norrie, A. (2013). Critical realism: Essential readings. Routledge. https://www.routledge.com/Critical-Realism-Essential-Readings/Archer-Bhaskar-CollierLawson-Norrie/p/book/9780415196321

Beheshti, M. (2016). Where is a Sage's thought; the relationship between museum and cultural scape; or what we are we looking for in museum. Kargadan, 4, 120-123.

Bell, S. (2012). Landscape: pattern, perception, and process. Routledge.

Bentley, I. (2004). Urban transformations: Power, people, and urban design. Routledge.

Bergamini, K. (2019). Urban Landscape/Urban Form. The Wiley Blackwell Encyclopedia of Urban and Regional Studies, 1-10. DOI: 10.1002/9781118568446.eurs0375

Bhaskar, R. (2008). Dialectic: The pulse of freedom. Routledge.

Bhaskar, R. (2013). A realist theory of science. Routledge.

Blaikie, N. (2000). Designing social research. Cambridge. Polity.

Blaikie, N. (2007). Approaches to social enquiry: Advancing knowledge. Polity.

Carmona, M., Heath, T., Oc, T., \& Tiesdell, S. (2003). Public Space-Urban Space, The Dimensions of Urban Design. Edisi.

Carmona, M., de Magalhães, C., \& Hammond, L. (Eds.). (2008). Public space: the management dimension. Routledge.

Chalmers, A. F. (2013). What is this thing called science? Hackett Publishing.

Chomsky, N. (2012). Making the future: Occupations, interventions, empire, and resistance. Penguin UK.

Conzen, M. R. (2004). Thinking about urban form: papers on urban morphology, 1932-1998. Peter Lang.

ACE, 16 (46) CC BY-ND 3.0 ES | UPC Barcelona, España | Redefining Urban Landscape regarding Scientific Realism 19 Philosophy of Science. DOI: http://dx.doi.org/10.1080/ace.16.46.9202 
Council of Europe, (2000). European landscape convention. European Treaty Series - № 176. https://rm.coe.int/1680080621

Cullen, G. (1961). Townscape. Architectural Review London. Britain

Cuthbert, A. R. (2008). The form of cities: Political economy and urban design. John Wiley \& Sons.

Diener, C., Herzog, J., Meili, M., de Meuron, P., Herz, M., Schmid, C., \& Topalović, M., (2015). The Inevitable Specificity of Cities. Lars Müller Publishers.

Elden, S. (2004). Understanding Henri Lefebvre. A\&C Black.

European Commission, (2016). EU's 7th Framework Programme for Research and Technological Development. https://ec.europa.eu/commission/presscorner/detail/en/MEMO 16 146

Faizi, M., \& Razzaghi, S. (2008). Landscape urbanism; New Approach in Landscape Architecture \& urban design. Baq e Nazar, 5(10), 27-36

Golkar, K. (2008). Conceptual Evolution of Urban Visual Environment; From Cosmetic Approach through to Sustainable Approach. Environmental Sciences, 5(4). https://www.sid.ir/en/journal/ViewPaper.aspx?id=139515

Golkar, K. (2006). The Concept of landscape. Abadi. Vol. 16 (53), 38-47.

Goonewardena, K., Kipfer, S., Milgrom, R., \& Schmid, C. (Eds.). (2008). Space, difference, everyday life: reading Henri Lefebvre. Routledge.

Goonewardena, K. (2012). Henri Lefebvre, State, Space, World: Selected Essays-Edited by Neil Brenner and Stuart Elden. International Journal of Urban and Regional Research, 36(2), 412-414. DOI: 10.1111/j.1468-2427.2012.01129_8.x

Gospodini, A. (2002). European cities in competition and the new'uses' of urban design. Journal of Urban Design, 7(1), 59-73. DOI: 10.1080/13574800220129231

Gurer, T. K. (2012). A theory for sustainability of townscape: typomorphology. In Green and Ecological Technologies for Urban Planning: Creating Smart Cities. IGl Global. https://www.igiglobal.com/chapter/theory-sustainability-townscape/66184

Harvey, D. (2011). The Future of the Commons. Radical History Review, 2011(109), 101-107. DOI: $\underline{10.1215 / 01636545-2010-017}$

Harvey, D. (2007). Neoliberalism and the City. Studies in Social Justice, 1(1), 2-13. DOI: 10.26522/ssj.v1i1.977

Hassard, J. (1993). Sociology and organization theory: Positivism, paradigms, and postmodernity (№. 20). Cambridge University Press. DOI: $\underline{10.1017 / C B O 9780511557651}$

Hume, R., \& Roberts, G. H. (1967). Hypophysitis and hypopituitarism: report of a case. British medical journal, 2(5551), 548. DOI: 10.1136/bmj.2.5551.548

ACE, 16 (46) CC BY-ND 3.0 ES | UPC Barcelona, España | Redefining Urban Landscape regarding Scientific Realism 20 Philosophy of Science. DOI: http://dx.doi.org/10.1080/ace.16.46.9202 
Jacobs, J. (1969). Strategies for helping cities. The American Economic Review, 59(4), 652-656. https://ideas.repec.org/a/aea/aecrev/v59y1969i4p652-56.html

Julier, G. (2005). Urban Designscapes and the Production of Aesthetic Consent. Urban Studies, 42(56), 869-887. DOI: $10.1080 / 00420980500107474$

Klingmann, A. (2007). Brandscapes: Architecture in the experience economy. MIT Press.

Knox, P. L. (2010). Cities and design. Routledge.

Kondracki, N. L., \& Wellman, N., (2002). Content analysis: Review of methods and their applications in nutrition education. Journal of Nutrition Education and Behavior, 34, 224-230. DOI: 10.1016/S14994046(06)60097-3

Kostof, S. (1991). The City Shaped: Urban Patterns and Meanings Through History. Bulfinch Pr.

Kostof, S. (1992). The City Assembled. The Elements of Urban form Through History. Thames and Hudson Ltd.

Kuhn, T. S. (2012). The Structure of Scientific Revolutions. University of Chicago Press.

Krier, R., \& Rowe, C. (1979). Urban Space. London: Academy Editions.

Lefebvre, H., \& Nicholson-Smith, D. (1991). The production of space. Blackwell: Oxford.

Lynch, K. (1984). Good City Form. MIT press.

Madanipour, A. (2007). Designing the city of reason: foundations and frameworks. Routledge.

Madanipour, A. (2010). Whose public space. Whose Public Space? International Case Studies in Urban Design and Development. Routledge.

Mansouri, A. (2004). An introduction to Landscape architecture identification. The Monthly Scientific Journal of Bagh-e Nazar, 1 (2), 69-78. http://www.bagh-sj.com/article 1489.html?lang=en

Merrifield, A. (1993). The struggle over place: redeveloping American Can in Southeast Baltimore. Transactions of the Institute of British Geographers, 18(1), 102-121. DOI: 10.2307/623071

Morris, A. E. J. (2013). History of urban form before the industrial revolution. Routledge.

Mumford, L. (1961). The city in history: Its origins, its transformations, and its prospects. Houghton Mifflin Harcourt.

Pakzad, J., (2006). Image of City; whatever be understood by Kevin Lynch. Abadi,16 (53), $20-25$.

Saroukhani, B. (1994). Methodologies in Social Science. Cultural Studies and Humanity Sciences Institute.

Sayer, A. (1999). Realism and Social Science. Sage.

ACE, 16 (46) CC BY-ND 3.0 ES | UPC Barcelona, España | Redefining Urban Landscape regarding Scientific Realism 
Schumpeter, J. A., Swedberg, R., Eklöf, M., \& Strandberg, G. (1994). Schumpeter: om skapande förstörelse och entreprenörskap. Ratio.

Schuyler, D. (1988). The New Urban Landscape. The Redefinition of City Form in Nineteenth Century America. The Johns Hopkins University Press.

Sitte, C. (2013). The Art of Building Cities: City Building According to Its Artistic Fundamentals. Martino Fine Books.

Soltani, A., Namdarian, A. (2010). An investigation of forces influences on urban space formation. HOVIATESHAHR, 5(7), 123-130. https://www.sid.ir/en/journal/ViewPaper.aspx?ID=197229

Taimouri, M. (2007). The Concept of Landscape. Memari Manzar.

Tavernor, R. (2004). From townscape to skyscape. Architectural Review, 78-83.

Taylor, N. (1999). The elements of townscape and the art of urban design. Journal of Urban Design, 4(2), 195-209. DOI: 10.1080/13574809908724446

UNESCO (1962). Meeting in Paris from 9 November to 12 December 1962.

Waldheim, C. (2006). The Landscape Urbanism Reader. Princeton Architectural Press.

Whistler, W. M., \& Reed, D. (1977). Townscape as a Philosophy of Urban Design. Council of Planning Librarians.

Zekavat, K. (2006). Strategic Framework of View Management of city. Abadi. 16 (53), 26-37.

Zieleniec, A. J. (2007). Space and social theory. Sage. 